\author{
Commentary
}

\title{
Indigenous Governance is an Adaptive Climate Change Strategy
}

\author{
Stephanie Irlbacher-Fox \\ Rachel MacNeill
}

Since the 1960s, scientists have been aware that human activity has resulted in a warming climate. This reality has and will continue to result in changes to the way we live.

The Arctic and Subarctic have held prominent places in discussions on climate change, in part because impacts here are so stark and clearly connected to the effects of changes in temperature. In popular discourse internationally, media narratives often focus on "charismatic megafauna": polar bears starving, venturing into towns, disoriented, hungry, drowning. ${ }^{1}$ In Canada, Indigenous and ally activism on climate change make the link with food security, personal safety, and cultural survival, employing stories of Indigenous hunters no longer able to reliably read the signs of the land due to "strange weather." ${ }^{2}$ Indigenous Peoples provide critical insights into how climate change results in immediate and important implications for humans. ${ }^{3}$ However, using Indigenous experiences as evidence for climate change is often where the conversation stops-it should instead be a starting point. The conversation needs to turn to how Indigenous 
Knowledge, cultures, and the ways of life grounding Indigenous decisionmaking authority are a viable, legitimate, sustainable, and adaptive climate change strategy.

Greta Thunberg, the world's newest global climate change conscience, has a simple message: that to stop climate change, different people must be given the power to make decisions and they must make different decisions, in different ways. And they must do it now. ${ }^{4}$ This sounds familiar to those of us living in the Northwest Territories, because Indigenous Peoples have been seeking increased control over decision-making at the local level, in various aspects of their lives, for a very long time.

So how might this figure into climate change adaptation and mitigation strategies? Echoing Greta Thunberg's message, different people must both be in charge and have the resources to make different decisions, and make them differently. In academia, where much of the thinking on climate change adaptation originates, much has been made of Indigenous responses to climate change framed as "resilience" (e.g., don't worry, Indigenous Peoples will bounce back), ${ }^{5}$ or "ecological grief" (e.g., worry, Indigenous Peoples cannot bounce back and this grief amplifies other social ills). ${ }^{6}$ Such analysis again provides compelling evidence for action, yet also paints a picture of peoples at the margins of power, at the mercy of forces operating at a macro level that is irrelevant to the locality of experience-a reality where Indigenous traditional territories have increasingly become the habitat more of mines than of caribou; and a reality that should simply be accepted: grieve, bounce back, adapt. Perform and ultimately acquiesce to settler colonial norms.

The only legitimate and probably sustainable climate change adaptation strategy for Indigenous Peoples starts with their continuing to know and understand their lands through being on and living with their lands, even if the power over land management or weather eludes them. Like many of the pressures faced by Indigenous Peoples, their climate change adaptation options are subject to settler colonial, societal, and institutional control. Settler colonial control over decision making operates in opposition to and at the expense of Indigenous control and Indigenous values. Settler control-through control of institutions, resources, and 
decision making-not only greatly narrows the options for Indigenous responses to climate change adaptation, but is also seen as a natural and acceptable societal norm.

This is a bad adaptive climate change strategy. However, a just, sustainable, and legitimate climate change adaptation strategy and tool is readily available: settler colonial governments and society recognizing and acting on their moral, personal, and societal responsibilities to restore Indigenous governance authorities and to institute respectful relations. In other words, the best climate change adaptation strategy is for governments (and voters) to support Indigenous governance of climate change strategies for their communities and territories, ensuring the provision of resources needed to accomplish targeted outcomes and goals.

Using the power and authority over their lands and people, recognized through negotiated rights-based agreements and/or rooted in cosmologies that understand Indigenous Peoples as part of their lands, many Indigenous governments have undertaken targeted culturally-based land-connection initiatives. These range from building land-based camps for uses from eco-tourism to healing, to major annual seasonal journeys through their traditional territories as ways to reconnect youth to their people and identities. These land-based acts are generative of identity and relationship, essential for closing the varied gaps and healing the individual and collective harms created by ongoing colonial impacts. Labelled by Indigenous scholars as "grounded normativity," simply put it is the ability for Indigenous Peoples to engage in cultural resurgences and forms of culturally-based being as the basis for their social and political norms. People who mix themselves with the land in profoundly respectful ways, come to love the land. Loving the land is a necessary precursor to protecting and learning how to adapt to its changes. Land-based practices, those everyday choices of Indigenous governments, communities, and individuals, enable Indigenous Peoples to make collective strategic choices in the face of climate change, which do not force them to further selfalienate from their lands, and that will not shift climate action onto the shoulders of future generations. 
A fundamental requirement for enacting Indigenous governance as an adaptive climate change strategy is for settler colonial society to get out of the way: respect Indigenous land relationships, honour treaties through fulfilling legal obligations, restore governance authorities, and institute specific actions to restore respectful societal relations (e.g., consult the Truth and Reconciliation Calls to Action). ${ }^{8}$ Climate adaptation on these terms would support Indigenous Peoples to lead us all in adapting to climate change on the lands that they have managed since time immemorial.

\section{Notes}

1. See, for example, Kimberley Richards, "People did not See 'Full Story'behind Iconic Starving Polar Bear Image, Photographer Says," Independent, August 6, 2018, https://www.independent.co.uk/news/world/americas/polar-bearphoto-starving-climate-change-nat-geo-cristina-g-mittermeier-a8479946. html; Max Boykoff et al., "Charismatic Megafauna": The Growing Power of Celebrities and Pop Culture in Climate Change Campaigns" (Kings College, London: Environment, Politics and Development Working Paper Series, 2010); "Russian Archipelago Ends State Of Emergency After Polar Bear Invasion," RadioFreeEurope/RadioLiberty, February 19, 2019, https:// www.rferl.org/a/russia-polar-bear-arctic/29777997.html; Bruce Barcott, "Polar Bear Cubs Drowning due to Sea Ice Loss, says report," The Guardian, July 19, 2011, https://www.theguardian.com/environment/2011/jul/19/ polar-bear-cubs-drowning-ice.

2. See, for example, a discussion on Inuit filmmaker Zacharias Kunuk's film: Smithsonian, "Qapirangajuq Indigenous Knowledge and Climate Change," March 30, 2011, Video, 1:23:41, https://www.youtube.com/ watch? $\mathrm{v}=\mathrm{kOha0liL0w} 4$.

3. Hina Alam, "Indigenous Communities See Effects of Climate Change Up Close, Conference Told," Edmonton Journal, March 6, 2018, https:// edmontonjournal.com/news/local-news/indigenous-communities-seeeffects-of-climate-change-up-close-conference-told.

4. The Guardian, 'I Want You to Panic': 16-year-old Issues Climate Warning at Davos, January 25, 2019, video, 2:55, https://www.theguardian.com/ science/video/2019/jan/25/i-want-you-to-panic-16-year-old-gretathunberg-issues-climate-warning-at-davos-video. 
5. See, for example, Ramos-Castillo et al., "Indigenous Peoples, Local Communities and Climate Change Mitigation," Climatic Change, Special Issue 40, no. 1 (January 2017): 1-4, and the collection of papers in that volume at https://link.springer.com/article/10.1007/s10584-016-1873-0.

6. A. Cunsolo Willox, "Climate Change as the Work of Mourning," Ethics and the Environment 17, no. 2 (2012): 137-164.

7. Glen Coulthard and Leanne Betasamosake Simpson, "Grounded Normativity / Place-Based Solidarity," American Quarterly 68, no. 2 (Johns Hopkins University Press, June 2016): 249-255.

8. Truth and Reconciliation Commission of Canada, Truth and Reconciliation Commisson of Canada: Calls to Action (2015), https://nctr.ca/assets/reports/ Calls to Action English2.pdf.

\section{Author}

Stephanie Irlbacher-Fox, $\mathrm{PhD}$, is the author of Finding Dabshaa (UBC Press, 2009), and scientific director of Hotiì ts'eeda in Yellowknife, Northwest Territories.

Rachel MacNeill, MA, is the knowledge translation advisor of Hotıì ts'eeda (nwtspor.ca). 